\title{
The Resurgence of Interest in Anti-Cancer Dendritic Cell Vaccines
}

\author{
Robert 0 Dillman MD* \\ AIVITA Biomedical, University of California, USA
}

*Corresponding author: Robert O Dillman, Chief Medical Officer for AIVITA Biomedical, University of California ,Hoag Cancer Institute, Irvine, CA. 92612, USA.

To Cite This Article: Robert O Dillman MD. The Resurgence of Interest in Anti-Cancer Dendritic Cell Vaccines. Am J Biomed Sci \& Res. 2019 - 5(3). AJBSR.MS.ID.000907. DOI: 10.34297/AJBSR.2019.05.000907.

Received: 眥September 13, 2019; Published: 眥September 19, 2019

\section{Opinion}

The ultimate appreciation of dendritic cells (DC) and their role in biology occurred in the fall of 2011 when Ralph Steinman was awarded the Nobel Prize for his seminal work on the discovery, characterization, and biological function of DC [1,2]. The enthusiasm for clinical application of DC as presenters of tumor antigens may have peaked before 2000 following initial positive clinical reports in melanoma and lymphoma $[3,4]$. It took a decade of clinical trials and evolution from an endpoint of progression-free survival to one of overall survival to gain FDA-approval of a DC-based treatment product for commercialization, namely, sipuleucel-T for the treatment of prostate cancer [5]. Unfortunately, that product was not greeted enthusiastically by healthcare providers and payors because of the limited improvement in survival, and the cost of a course of therapy. Among dendritic cell vaccines (DCV), sipuleucel-T is unique in that it is an intravenous therapy that contains a mix of leukocytes stimulated by a vector containing prostatic acid phosphatase and granulocyte macrophage colony stimulating factor (GM-CSF) that was arguably more of an adoptive cell therapy than a vaccine.

There have been no additional treatment indications for similar products. Meanwhile, numerous small trials of antigen-loaded DC as traditional vaccines injected subcutaneously or intradermally have yielded some encouraging proof-of-principle results in terms of induction or enhancement of antigen-specific immune responses, but not much in the way of clinical benefit [6-8]. It should be noted that a randomized trial of autologous DC vaccine versus dacarbazine in patients with advanced disease is considered a negative trial even though the DC-treated patients did just as well but with much less toxicity [9]. Despite the limited evidence of survival benefit in patients treated with DCV, there is continuing and renewed interest in DCV especially as the limitations of checkpoint-inhibitor immunotherapy become more apparent over time, and the rationale for vaccines as an additive or synergistic therapy remains strong $[10,11]$. Some of the reasons for continuing to focus on DC-based vaccines to deliver tumor antigens include

a) The critical role of DC in the orchestration of the adaptive immune response [2]

b) The theoretical benefits of loading DC with antigen ex vivo, away from the immunosuppressive tumor microenvironment [10]

c) The most important component of any vaccine is its antigens, and there is increasing appreciation of autologous tumor antigens including patient-specific antigens and neoantigens as more rationale targets for vaccine responses than shared peptides or allogeneic antigens $[10,12,13]$

d) A randomized phase II trial demonstrated the superiority of injecting autologous DC presenting antigens from irradiated autologous tumor cells (ITC) over subcutaneous injection of autologous ITC that rely on in vivo antigen loading of DC $[14,15]$ and

e) Identification of ways to potentially improve the potency of antigen-loaded DC $[11,16]$. With regard to autologous antigens, it has long been the author's opinion that antigens derived from relatively pure cultures of autologous tumor cells is a better source than bulk autologous tumor with its large component of nonmalignant cells and immunosuppressive cells [17].

It is noteworthy that to date large randomized trials of DC loaded with autologous antigens derived from bulk tumor, have been disappointing [18-20]. In conclusion, there is a strong rationale for DC-based vaccines to present patient-specific autologous tumor antigens as a component of immunotherapy, and some encouraging clinical trial data. A plausible explanation for the apparent failures of so many DC-based vaccine trials is the limitations of the antigens that were being presented. Ongoing trials utilizing better sources of patient-specific autologous tumor antigen may yield better results. 


\section{References}

1. Steinman RM, Cohn ZA (1973) Identification of a novel cell type in peripheral lymphoid organs of mice. J Exp Med 137: 1142-1162.

2. Steinman RM (2012) Decisions about dendritic cells: past, present, and future. Ann Rev Immunol 30: 1-22.

3. Hsu FJ, Benike C, Fagnoni F, Liles TM, Czerwinski D, et al. (1996) Vaccination of patients with B-cell lymphoma using autologous antigen-pulsed dendritic cells. Nat Med 2(1): 52-58.

4. Nestle FO, Alijagic S, Gilliet M, Sun Y, Grabbe S, et al. (1998) Vaccination of melanoma patients with peptide- or tumor lysate-pulsed dendritic cells. Nat Med 4(3): 328-332.

5. Kantoff PW, Higano CS, Shore ND, Berger ER, Small EJ et al. (2010) Sipuleucel-T immunotherapy for castration resistant prostate cancer. N Engl J Med 363(5): 411-422.

6. Palucka K, Banchereau J (2013) Dendritic-cell-based therapeutic cancer vaccines. Immunity 39(1): 38-48.

7. Dillman RO, Cornforth AN, Nistor GI (2016) Dendritic cell vaccines for melanoma: past, present, and future. Melanoma Manag 3(4): 267-283.

8. Sabado RL, Balan S, Bhardwaj N (2017) Dendritic cell-based immunotherapy. Cell Res 27(1): 74-95.

9. Schadendorf D, Ugurel S, Schuler Thurner B,Nestle FO, Enk A, et al (2006) Dacarbazine (DTIC) versus vaccination with autologous peptide-pulsed dendritic cells (DC) in first-line treatment of patients with metastatic melanoma: a randomized Phase III trial of the DC study group of the DeCOG Ann Oncol 17(4): 563-570.

10. Dillman RO (2017) Is there a role for therapeutic cancer vaccines in the age of checkpoint inhibitors? Hum Vaccin Immunother 13(3): 528-532.

11. Saxena M, Bhardwaj N (2018) Re-emergence of dendritic cell vaccines for cancer treatment. Trends Cancer 4(2): 119-137.
12. Schumacher TN, Schreiber RD (2015) Neoantigens in cancer immunotherapy. Science 348(6230): 69-74.

13. Türeci Ö, Vormehr M, Diken M, Boegel S, Sahin U, et al. (2016) Mutanome directed cancer immunotherapy. Curr Opin Immunol 39: 14-22.

14. Dillman RO, Cornforth AN, Depriest C, Mc Clay EF, Amatruda TT, et al. (2012) Tumor stem cell antigens as consolidative active specific immunotherapy: a randomized phase II trial of dendritic cells versus tumor cells in patients with metastatic melanoma. J Immunother 35(8): 641649.

15. Dillman RO, Cornforth AN, Nistor GI, McClay EF, Amatruda TT, et al. (2018) Randomized phase II trial of autologous dendritic cell vaccines versus autologous tumor cell vaccines in metastatic melanoma: 5-year follow up and additional analyses. J Immunother Cancer 6(1): 19.

16. Wilgenhof S, Corthals J, Heirman C, Van Baren N, Lucas S, et al. (2016) Phase II study of autologous monocyte-derived mRNA electroporated dendritic cells (TriMixDC-MEL) plus ipilimumab in patients with pretreated advanced melanoma. J Clin Oncol 34(12): 1330-1338.

17. Dillman RO, Nayak SK, Beutel L (1993) Establishing in vitro cultures of autologous tumor cells for use in active specific immunotherapy. J Immunother 14(1): 65-69.

18. Argos press release (2017) Independent data monitoring committee recommends discontinuation of the ADAPT phase 3 clinical trial of rocapuldencel-t in metastatic renal cell carcinoma for futility following its planned interim data review.

19. Liau LM, Ashkan K, Tran DD, Campian JL, Trusheim JE, et al. (2018) First results on survival from a large phase 3 clinical trial of an autologous dendritic cell vaccine in newly diagnosed glioblastoma. J Transl Med 16(1): 142 .

20. Buchroithner J, Erhart F, Pichler J, Widhalm G, Preusser M, et al. (2018) Audencel immunotherapy based on dendritic cells has no effect on overall and progression free survival in newly diagnosed glioblastoma: a phase II randomized trial. Cancers (Basel) 10(10): E372. 